\title{
Karakteristik Purpura Henoch-Schönlein pada Anak di Rumah Sakit Cipto Mangunkusumo
}

\author{
Ihat Sugianti, Arwin AP Akib, Soedjatmiko \\ Departemen Ilmu Kesehatan Anak Fakultas Kedokteran Universitas Indonesia/ Rumah Sakit Dr. \\ Cipto Mangunkusumo, Jakarta
}

Latar belakang. Purpura Henoch-Schönlein (PHS) merupakan sindrom klinis yang disebabkan vaskulitis akut sistemik yang paling sering pada anak. Manifestasi klinis melibatkan berbagai organ, seperti kulit, sendi, gastrointestinal, dan ginjal dengan rekurensi terjadi pada hampir 50\% kasus.

Tujuan. Mengetahui manifestasi klinis, laboratorium, serta rekurensi PHS anak di Indonesia.

Metode. Penelitian deskriptif retrospektif dari rekam medis pasien anak berusia 0-18 tahun dengan diagnosis PHS selama periode 1 Januari 2009 hingga 31 Desember 2012 di Rumah Sakit Cipto Mangunkusumo, Jakarta.

Hasil. Terdapat 71 kasus PHS, rentang usia 2 sampai 16 tahun dan tersering pada kelompok 6-8 tahun. Proporsi anak perempuan lebih tinggi dibanding laki-laki (rasio 1,2:1). Semua pasien mengalami purpura palpabel, manifestasi tersering adalah gangguan gastointestinal (79\%), artritis atau artralgia (68\%), dan keterlibatan ginjal (41\%). Riwayat infeksi yang mendahului gejala PHS didapatkan 56\% kasus. Peningkatan laju endap darah $(88 \%)$ dan trombositosis $(60 \%)$ merupakan kelainan laboratorium yang paling sering ditemukan, diikuti hematuria (41\%), leukositosis (32\%), dan anemia (31\%). Penurunan fungsi ginjal ditemukan 6/42 kasus. Perbaikan gejala klinis terlihat dalam waktu kurang dari 4 minggu untuk manifestasi kulit, gastrointestinal, dan persendian. Sebanyak 18/24 subjek dengan hematuria mengalami perbaikan dalam waktu 6 bulan. Penurunan fungsi ginjal menetap tidak ditemukan. Rekurensi didapatkan 5/57 subjek yang memiliki data pemantauan.

Kesimpulan. Manifestasi klinis tersering pada PHS adalah purpura palpabel, gangguan gastrointestinal, artritis atau artralgia, dan keterlibatan ginjal. Pemeriksaan darah perifer lengkap dan urinalisis sebaiknya dilakukan pada semua pasien PHS untuk mendukung diagnosis dan menilai keterlibatan ginjal. Pemantauan minimal dilakukan selama 6 bulan untuk menilai keterlibatan ginjal yang mungkin timbul terlambat serta rekurensi. Sari Pediatri 2014;16(2):128-35.

Kata kunci: purpura Henoch-Schönlein, anak, karakteristik, Indonesia

Alamat korespondensi:

Prof. Dr. Arwin AP. Akib, Sp.A(K). Staf Divisi Alergi Imunologi RSUPN Dr. Cipto Mangunkusumo. Jl. Diponegoro 71, Jakarta. Telp. (021) 3907740. E-mail: arwin_ali@idai.or.id

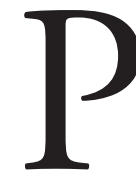

urpura Henoch-Schönlein (PHS) merupakan suatu sindrom klinis yang disebabkan oleh vaskulitis yang paling sering pada anak. ${ }^{1-4}$ Insiden PHS pertahun mencapai 10-20 per 100.000. ${ }^{2}$ Purpura Henoch-Schönlein dapat mengenai 
semua usia, tetapi 50\% kasus terjadi pada usia kurang dari 5 tahun dan $75 \%$ kasus terjadi pada usia kurang dari 10 tahun.

Puncak kejadiaan PHS pada usia 5 sampai 6 tahun. ${ }^{1,3,5}$ Laki-laki lebih sering terkena dengan perbandingan 1,5-2 kali lebih besar dibanding perempuan. ${ }^{6,7}$ Pada umumnya, PHS dianggap sebagai penyakit ringan dengan prognosis baik, tetapin hampir $40 \%$ pasien PHS memerlukan rawat inap akibat manifestasi akut seperti glomerulonefritis, hipertensi, perdarahan gastrointestinal, artralgia, nyeri abdomen, dan intususepsi. ${ }^{8,9}$

Di Indonesia, insiden PHS belum diketahui secara pasti. Berdasarkan data yang didapatkan di Departemen Ilmu Kesehatan Anak (IKA) Fakultas Kedokteran Universitas Indonesia-Rumah Sakit Cipto Mangunkusumo (FKUI-RSCM), didapatkan kecenderungan peningkatan kasus baru. Di bulan Juli sampai dengan Desember 2006 didapatkan 10 kasus baru PHS, lebih besar apabila dibandingkan hanya 23 kasus baru yang ditemukan dalam kurun waktu 5 tahun sebelumnya (1998-2003). ${ }^{10}$

Diagnosis PHS ditegakkan berdasarkan gejala klinis. Apabila ditemukan 2 dari 4 kriteria, yaitu usia $\leq 20$ tahun pada awitan sakit,purpura palpabel nontrombositopenia, nyeri akut abdomen difus yang bertambah berat setelah makan, dan biopsi yang memperlihatkan granulosit pada dinding arteriol atau venula. ${ }^{11}$

Penyebab PHS sampai saat ini belum dapat ditentukan. Beberapa mikroorganisme dan alergen telah diduga sebagai faktor pemicu, di antaranya adalah Streptococcus beta-hemolyticus tipe A. ${ }^{2,3}$ Peranan mikroorganisme sebagai pencetus PHS didukung dengan ditemukannya riwayat infeksi saluran napas akut sebelum awitan sakit pada hampir 50\% penderita PHS. ${ }^{12}$ Faktor genetik juga diduga turut memengaruhi kerentanan dan manifestasi klinis anak dengan PHS. ${ }^{1,7,13}$ Imunoglobin A dipercaya memiliki peranan penting dalam patogenesis PHS. Hal tersebut diperlihatkan dengan adanya peningkatan konsentrasi IgA serta deposit IgA di dinding pembuluh darah dan mesangium ginjal..$^{714}$

Sebagian besar kasus PHS dapat sembuh tanpa memerlukan pengobatan dan tidak menimbulkan sekuele berarti. ${ }^{13}$ Pengobatan yang diberikan bersifat simtomatis dan suportif. ${ }^{1,2,7}$ Rekurensi pada PHS merupakan keadaan yang sering timbul pada hampir $50 \%$ penderita. Kekerapan timbulnya rekurensi memperbesar kemungkinan timbulnya kerusakan ginjal permanen. Komplikasi berat pada PHS dikaitkan dengan keterlibatan ginjal yang merupakan salah satu indikator prognosis buruk PHS dan memerlukan pengobatan khusus seperti pemberian kortikosteroid ataupun imunoglobulin intravena. ${ }^{7,15}$

\section{Metode}

Studi deskriptif retrospektif dari rekam medis pasien PHS anak yang dirawat baik di instalasi rawat jalan ataupun instalasi rawat inap RS Cipto Mangunkusumo sejak periode 1 Januari 2009 sampai dengan Desember 2012. Subjek penelitian adalah semua pasien PHS anak berusia kurang dari 18 tahun. Berdasarkan data yang didapat, dicatat nama, jenis kelamin, tanggal diagnosis ditegakkan, usia, tekanan darah, manifestasi klinis (kelainan kulit, gejala gastrointestinal, artritis atau artralgia, kelainan ginjal, manifestasi lain), hasil laboratorium (darah tepi, protein urin, hematuria, ureum, kreatinin, darah samar tinja), pengobatan yang diberikan, tanggal perbaikan gejala klinis dan tanggal terjadinya rekurensi. Seluruh data diolah dan dianalisis secara deskriptif dengan menggunakan program SPSS 17.0.

\section{Hasil}

Selama periode penelitian berhasil dikumpulkan 71 kasus PHS. Anak perempuan lebih banyak dibanding laki-laki dengan perbandingan 1,2:1. Rentang usia subjek 2-16 tahun dengan median usia 7,1 tahun. Puncak kejadian pada usia 6-9 tahun. Keterangan mengenai jenis infeksi yang didapatkan, diperoleh 4 subjek mengalami infeksi saluran napas atas dan 2 subjek mengalami infeksi varisela pada 6 dari 22 subjek dengan riwayat infeksi sebelum awitan sakit (Tabel 1).

Semua pasien mengalami purpura palpabel (100\%). Gejala gastrointestinal ditemukan 56 (79\%) subjek, dengan keluhan terbanyak berupa nyeri abdomen disertai mual dan muntah (36\%). Pada 13 subjek didapatkan keluhan buang air besar berdarah atau hematemesis. Gangguan persendian didapatkan $48(68 \%)$ kasus, dan keterlibatan ginjal ditemukan 24 (41\%) kasus. Manifestasi PHS yang jarang, seperti kelainan neurologis berupa nyeri kepala didapatkan 1 
Tabel 1. Karakteristik dasar subjek

\begin{tabular}{lcc}
\hline Variabel & Jumlah & Persen \\
\hline Jenis kelamin & 33 & 47 \\
$\quad$ Laki-laki & 38 & 53 \\
$\quad$ Perempuan & & \\
Usia saat didiagnosis (tahun) & 0 & 0 \\
$\quad<2$ & 33 & 47 \\
$2-7$ & 38 & 53 \\
$>7$ & & 0 \\
Riwayat keluarga dengan PHS & 0 & 100 \\
$\quad$ Ada & 71 & 31 \\
Tidak ada & & 24 \\
Riwayat adanya infeksi 3 minggu sebelum awitan sakit & 22 & 45 \\
$\quad$ Ada & 17 & \\
Tidak ada & 32 & \\
Tidak ada keterangan & & \\
&
\end{tabular}

Tabel 2. Karakteristik klinis subjek

\begin{tabular}{lcc}
\hline Manifestasi klinis & $\begin{array}{c}\text { Jumlah } \\
(\mathrm{n}=71)\end{array}$ & $\begin{array}{c}\text { Persentase } \\
(\%)\end{array}$ \\
\hline Purpura palpabel di ekstremitas atau bokong & 71 & 100 \\
Purpura di regio lain & 21 & 30 \\
Keluhan gastrointestinal & 56 & 79 \\
Nyeri abdomen & 15 & 21 \\
Muntah & 2 & 3 \\
Mual & 1 & 1 \\
BAB berdarah & 1 & 1 \\
Nyeri abdomen, muntah, mual & 25 & 36 \\
Nyeri abdomen dan BAB berdarah/hematemesis & 12 & 17 \\
Artritis atau artralgia di sendi lutut atau pergelangan kaki & 48 & 68 \\
Artritis atau artralgia di tempat lain & 7 & 10 \\
Gejala penyerta lainnya & & \\
Demam & 6 & 9 \\
Nyeri kepala & 1 & 1 \\
Edema skrotum & 3 & 4 \\
Edema anasarka & 2 & 3 \\
Edema tungkai & 4 & 6 \\
BAK keruh & 3 & 4 \\
Batuk dan pilek & 1 & 1 \\
Tidak ada & 51 & 72 \\
Tekanan darah & & \\
Normotensi & 53 & 75 \\
Hipertensi & 8 & 11 \\
Tidak ada data & 10 & 14 \\
Gejala pertama timbul & & \\
Purpura & 18 & 25 \\
Keluhan gastrointestinal & 9 & 13 \\
Artritis atau artralgia & 3 & 58 \\
Purpura dengan keluhan gastrointestinal/artralgia & 41 & \\
\hline
\end{tabular}


subjek dan edema skrotum 3 subjek. Sembilan subjek mengalami keluhan gastrointestinal sebagai keluhan pertama PHS dan 2 di antaranya menjalani operasi apendektomi karena gejalanya menyerupai abdomen akut (Tabel 2.).

Pemeriksaan darah perifer lengkap hanya didapatkan 62 subjek. Peningkatan laju endap darah (LED) $(88 \%)$ dan trombositosis (60\%) merupakan kelainan laboratorium yang paling sering ditemukan, diikuti dengan leukositosis (32\%), dan anemia (31\%).
Median nilai LED 23(3-75) $\mathrm{mm} / \mathrm{jam}$. Hematuria merupakan manifestasi kelainan ginjal yang sering ditemukan (41\%) dan 6/42 subjek mengalami penurunan fungsi ginjal (Tabel 3). Pemeriksaan darah samar tinja positif ditemukan $6 / 8$ subjek dan hipoalbuminemia 6/12. Penurunan konsentrasi serum komplemen C3 kurang dari $80 \mathrm{mg} / \mathrm{dL}$ didapatkan 2/7 subjek. Biopsi kulit dilakukan pada 1 subjek karena morfologi lesi kulit tidak khas dengan hasil gambaran biopsi sesuai dengan vaskulitis leukositoklastik. Satu

Tabel 3. Karakteristik laboratorium subjek

\begin{tabular}{lcc}
\hline Hasil laboratorium & Jumlah & Persentase $(\%)$ \\
\hline Darah perifer lengkap $(\mathrm{n}=62)$ & & \\
Anemia & 19 & 31 \\
Leukositosis & 20 & 32 \\
Trombositosis & 37 & 60 \\
Penurunan LFG $<90 \mathrm{ml} / \mathrm{m} / \mathrm{m}^{2}(\mathrm{n}=42)$ & 6 & 14 \\
Peningkatan LED $(\mathrm{n}=33)$ & 29 & 88 \\
Proteinuria $(\mathrm{n}=59)$ & 17 & 29 \\
Hematuria $(\mathrm{n}=59)$ & 24 & 41 \\
\hline
\end{tabular}

Tabel 4. Gambaran rekurensi pada subjek penelitian

\begin{tabular}{|c|c|c|c|c|c|c|}
\hline $\begin{array}{l}\text { Usia saat } \\
\text { awitan } \\
\text { sakit }\end{array}$ & Jenis kelamin & Gejala awitan sakit & $\begin{array}{l}\text { Awitan } \\
\text { rekurensi } \\
\text { (bulan) }\end{array}$ & $\begin{array}{l}\text { Frekuensi } \\
\text { rekurensi }\end{array}$ & Gejala rekurensi & Terapi rekurensi \\
\hline $\begin{array}{l}6 \text { tahun } 9 \\
\text { bulan }\end{array}$ & Perempuan & $\begin{array}{l}\text { Purpura, nyeri } \\
\text { abdomen, } \\
\text { hematuria, } \\
\text { proteinuria, dan } \\
\text { penurunan LFG }\end{array}$ & 36 & 1 & $\begin{array}{c}\text { Purpura, } \\
\text { hematoschezia, } \\
\text { dan hematuria }\end{array}$ & $\begin{array}{c}\text { Metilprednisolon } 2 \\
\mathrm{mg} / \mathrm{kgBB} / \mathrm{hari}\end{array}$ \\
\hline $\begin{array}{l}8 \text { tahun } 5 \\
\text { bulan }\end{array}$ & Perempuan & $\begin{array}{l}\text { Purpura, nyeri } \\
\text { abdomen, hematuria } \\
\text { dan proteinuria }\end{array}$ & 14 & 1 & $\begin{array}{c}\text { Purpura, } \\
\text { hematuria } \\
\text { makroskopik }\end{array}$ & $\begin{array}{c}\text { Metilprednisolon } \\
2 \mathrm{mg} / \mathrm{kgBB} / \mathrm{hari} \\
\text { selama total } 2 \text { bulan }\end{array}$ \\
\hline $\begin{array}{l}8 \text { tahun } 1 \\
\text { bulan }\end{array}$ & Perempuan & $\begin{array}{l}\text { Purpura, nyeri } \\
\text { abdomen, } \\
\text { hematoschezia, } \\
\text { hematuria, } \\
\text { proteinuria, } \\
\text { penurunan LFG }\end{array}$ & 8 dan 11 & 2 & $\begin{array}{c}\text { Purpura, } \\
\text { hematuria, dan } \\
\text { artralgia (kedua } \\
\text { rekurensi) }\end{array}$ & $\begin{array}{l}\text { Prednison } 2 \mathrm{mg} / \\
\text { kgBB/hari selama } \\
\text { total } 2 \text { bulan }\end{array}$ \\
\hline 7 tahun & Laki-laki & Purpura, hematuria & 4 & 1 & $\begin{array}{c}\text { Purpura dan } \\
\text { hematuria }\end{array}$ & $\begin{array}{l}\text { Triamsinolon } 1 \\
\text { mg/kgBB selama } 1 \\
\text { minggu }\end{array}$ \\
\hline $\begin{array}{l}4 \text { tahun } 9 \\
\text { bulan }\end{array}$ & Laki-laki & $\begin{array}{l}\text { Purpura, nyeri } \\
\text { abdomen, melena, } \\
\text { proteinuria, dan } \\
\text { hematuria }\end{array}$ & 1 dan 10 & 2 & $\begin{array}{l}\text { Nyeri abdomen, } \\
\text { hematuria } \\
\text { makroskopik }\end{array}$ & $\begin{array}{l}\text { Metilprednisolon } \\
2 \mathrm{mg} / \mathrm{kgBB} \text { selama } \\
\text { total } 2 \text { bulan }\end{array}$ \\
\hline
\end{tabular}


pasien menjalani pemeriksaan biopsi ginjal karena timbul rekurensi dengan manifestasi makrohematuria. Hasil biopsi ginjal memperlihatkan adanya kelainan glomerulus minimal dengan glomerulosklerosis subtotal yang dapat ditemukan pada nefropati IgA.

Terapi steroid diberikan pada 64 (90\%) kasus, baik sebagai terapi tunggal ataupun kombinasi dengan obat lainnya, seperti antagonis reseptor $\mathrm{H}-2$, proton pump inhibitor, atau antihipertensi. Steroid tersering yang digunakan adalah metilprednisolon (76\%), triamsinolon (16\%), dan prednison (8\%). Satu kasus mendapatkan terapi anti inflamasi non steroid yaitu natrium diklofenak karena keluhan artralgia yang menonjol. Tiga kasus tidak mendapatkan pengobatan karena gejala yang dominan berupa purpura palpabel. Terapi imunosupresif diberikan pada 5 kasus dengan nefritis PHS berupa siklofosfamid 4 kasus dan azathioprin 1 kasus karena perburukan hematuria dengan pemberian steroid.

Pada 14 kasus, tidak didapatkan data pemantauan dan lama pemantauan untuk masing-masing kasus bervariasi dengan median 1,5 (0,5-33) bulan. Sebagian besar keluhan purpura, gangguan gastointestinal, dan artralgia, menghilang dua minggu setelah awitan sakit. Tidak didapatkan purpura yang menetap lebih dari satu bulan. Satu kasus mengalami gangguan gastrointestinal berupa nyeri abdomen yang menetap lebih dari 4 minggu, tetapi dengan intensitas nyeri yang semakin berkurang. Pada satu subjek, keluhan artralgia menetap lebih dari empat minggu tanpa disertai keluhan lainnya. Pada empat subjek, hematuria menetap lebih dari enam bulan, tetapi tanpa disertai penurunan fungsi ginjal ataupun keluhan lainnya. Lima subjek yang mengalami penurunan fungsi ginjal saat awitan sakit tidak ada yang bersifat menetap. Satu subjek penelitian mengalami perbaikan fungsi ginjal setelah 20 bulan pasca awitan sakit. Gambaran rekurensi pada 5 kasus tertera pada Tabel 4 .

\section{Pembahasan}

Penelitian ini merupakan penelitian tentang PHS anak yang memuat data tentang manifestasi klinis, pemeriksaan laboratorium, pengobatan, serta data rekurensi. Waktu pemantauan yang bervariasi serta tidak semua rekam medis memuat data-data epidemiologis dan laboratorium merupakan keterbatasan dari penelitian kami.
Proporsi anak laki-laki dan perempuan PHS ditemukan bervariasi pada berbagai penelitian. Sebagian besar penelitian mendapatkan insiden lebih tinggi pada anak laki-laki dengan jumlah 1,5 sampai 2 kali lebih besar dibandingkan perempuan, sedangkan penelitian lain menunjukkan dominasi perempuan dibandingkan laki-laki. ${ }^{5}$ Pada penelitian kami, perbandingan perempuan lebih tinggi dibanding laki-laki $(1,2: 1)$ dengan rentang usia 2-15,7 tahun, median usia 7,1 tahun dan kelompok subjek terbanyak pada usia 6-9 tahun. Hasil ini sama dengan penelitian Tohmaz $\mathrm{dkk}^{16}$ yang memiliki rasio jenis kelamin perempuan lebih besar dibanding laki-laki, subjek dengan rentang usia 2-12 tahun, dan puncak kejadian pada usia 6-8 tahun. Variasi hasil tersebut dapat disebabkan oleh besar sampel yang berbeda di berbagai penelitian, serta dipengaruhi oleh perbedaan waktu pengambilan sampel, ras, geografi daerah, dan sumber data yang dikumpulkan.

Etiologi utama PHS masih belum dapat ditentukan, tetapi infeksi diduga kuat sebagai pemicu utama timbulnya PHS. ${ }^{1}$ Coppo $\mathrm{dkk}^{17}$ mengidentifikasi infeksi sebagai faktor pemicu pada $41 \%$ kasus, sedangkan Aalberse $\mathrm{dkk}^{18}$ mengidentifikasi adanya infeksi saluran napas atas sebelum atau saat timbulnya purpura pada $61 \%$ kasus. Pada penelitian kami, riwayat infeksi didapatkan 56\% subjek yang memiliki data, sedangkan 32 subjek tidak didapatkan keterangan tentang riwayat infeksi sebelum awitan sakit. Infeksi saluran napas atas merupakan jenis infeksi yang paling sering dikaitkan dengan PHS. Gonzales dkk ${ }^{12}$ dalam penelitiannya mendapatkan bahwa 41\% anak dengan PHS memiliki riwayat infeksi saluran napas atas. Pada penelitian kami, jenis infeksi yang didapat tidak tertulis jelas di rekam medis, tetapi batuk dan pilek didapatkan 4 di antara 22 subjek dengan riwayat infeksi. Virus Varicella-Zooster juga diduga sebagai salah satu faktor pemicu PHS. ${ }^{7}$ Kalman $\mathrm{dkk}^{19}$ melaporkan kasus PHS yang didahului oleh infeksi varisela. Pada dua subjek penelitian kami didapatkan riwayat infeksi varisela 2 minggu sebelum awitan PHS.

Diagnosis PHS ditegakkan apabila didapatkan dua dari 4 kriteria sesuai kriteria ACR tahun $1990 .{ }^{11}$ Pada penelitian kami, purpura palpabel ditemukan pada seluruh subjek penelitian dengan lokasi utama sesuai dengan berbagai literatur yang ada, yaitu tungkai dan bokong. Berdasarkan penelitian sebelumnya, gejala gastrointestinal ditemukan 35\%-85\% kasus PHS, gejala tersering berupa nyeri abdomen berat. ${ }^{6}$ 
Hasil tersebut sesuai dengan penelitian kami yang menemukan $79 \%$ kasus gejala gastrointestinal, dengan nyeri abdomen yang disertai mual atau muntah sebagai gejala tersering $(36 \%)$. Perdarahan gastrointestinal ditemukan pada $18 \%$ kasus, lebih kecil apabila dibandingkan penelitan Kumar dkk ${ }^{4}(47 \%)$, tetapi hampir sama dengan penelitian Widjajanti ${ }^{20}$ (16\%). Keluhan gastrointestinal merupakan gejala pertama yang timbul pada 9 subjek (13\%), dan 2 di antaranya menjalani operasi apendektomi. Laparotomi eksplorasi juga didapatkan pada 2 subjek penelitian Kumar dkk ${ }^{4}$ saat keluhan gastrointestinal berupa gejala abdomen akut timbul sebagai gejala pertama tanpa disertai kelainan di kulit atau persendian. Pada penelitian Widjajanti didapatkan $5(1,4 \%)$ kasus yang awalnya diduga apendisitis dan menjalani operasi apendektomi. ${ }^{20}$

Artritis atau artralgia ditemukan 68\% kasus dan merupakan gejala pertama yang timbul pada $4 \%$ kasus. Gangguan neurologis merupakan manifestasi yang jarang ditemukan, dan paling sering berupa nyeri kepala dan gangguan kesadaran. Penelitian Aalberse $\mathrm{dkk},{ }^{18}$ pada populasi anak dengan PHS di Belanda, mendapatkan 3\% subjek penelitian yang mengalami manifestasi neurologis berupa sakit kepala. Pada penelitian kami didapatkan 1 subjek mengalami nyeri kepala dan 3 mengalami edema skrotum.

Prognosis PHS terutama dikaitkan dengan adanya keterlibatan ginjal. Insiden keterlibatan ginjal bervariasi antara 20\%-50\%. ${ }^{6,21}$ Pada penelitian kami, didapatkan $41 \%$ kasus insiden keterlibatan ginjal, lebih rendah apabila dibandingkan penelitian Trapani $\mathrm{dkk},{ }^{22}$ tetapi lebih tinggi bila dibandingkan dengan penelitian Aki. ${ }^{21}$ Sesuai dengan studi sebelumnya, hematuria merupakan kelainan ginjal yang paling sering ditemukan. ${ }^{6,18,23}$ Pada 8 subjek penelitian, hematuria menjadi satu-satunya kelainan ginjal yang timbul. Satu subjek mengalami sindrom nefrotik-nefritis dan 6 mengalami penurunan fungsi ginjal. Tidak didapatkan subjek dengan gagal ginjal terminal. Trapani $\mathrm{dkk}^{22}$ dalam penelitiannya mendapatkan hasil yang sama, yaitu satu pasien mengalami sindrom nefrotik-nefritis dan tidak ada yang mengalami gagal ginjal terminal. Tigabelas persen subjek hipertensi dan 1 tanpa disertai oleh manifestasi ginjal lainnya. Hasil tersebut lebih besar dibandingkan dengan data hipertensi yang didapatkan pada penelitian Aalberse dkk, ${ }^{18}$ yaitu 3\%. Narchi ${ }^{24}$ dalam telaah sistemiknya, menyatakan keterlibatan ginjal pada 97\% pasien PHS akan timbul dalam waktu
6 bulan sejak awitan sakit. Pada penelitian kami, keterlibatan ginjal pada semua subjek ditemukan dalam waktu kurang dari 2 minggu sejak awitan sakit dan tidak ada yang mendahului timbulnya purpura.

Diagnosis PHS ditegakkan berdasarkan tanda dan gejala klinis. Sampai saat ini, belum ada pemeriksaan laboratorium yang bersifat diagnostik untuk PHS, tetapi temuan laboratorium tertentu dapat menunjang diagnosis dan menyingkirkan diagnosis diferensial. ${ }^{13}$ Sesuai dengan hasil penelitian sebelumnya, data kami menunjukkan adanya anemia (31\%) dan leukositosis (32\%) pada 62 subjek yang memiliki data laboratorium. Peningkatan LED ditemukan 29/33 subjek yang diperiksa. Kumar $\mathrm{dkk}^{4}$ mendapatkan insiden peningkatan LED pada 19/22 subjek penelitiannya, besarannya hampir sama pada penelitian kami. Penelitian Trapani $\mathrm{dkk}^{22}$ mendapatkan insiden anemia, leukositosis, dan peningkatan LED yang lebih kecil apabila dibandingkan dengan penelitian kami, yaitu berturut-turut 14\%, 21\%, dan 57\%. Perbedaan insiden peningkatan LED antara penelitian kami dan Trapani dkk dapat disebabkan karena perbedaan insiden anemia yang lebih tinggi pada penelitian kami, perbedaan nilai titik potong LED yang digunakan, serta faktor lain yang dapat memengaruhi LED yang tidak dapat kami teliti dalam studi ini. Trombositosis merupakan kelainan laboratorium yang sering ditemukan dan diduga berkaitan erat dengan nyeri abdomen dan perdarahan gastrointestinal, tetapi tidak berkaitan dengan nefritis ataupun artritis PHS. ${ }^{21}$ Trombositosis dialami $60 \%$ dari 62 subjek yang memiliki data laboratorium, insidennya hampir sama dengan yang ditemukan pada penelitian Kumar $\mathrm{dkk}^{4}$ yaitu $56 \%$.

Sebagian besar PHS dapat sembuh tanpa pengobatan. Pada keadaan ringan, diberikan tata laksana suportif berupa pemberian hidrasi, nutrisi, dan pemberian obat simtomatis. ${ }^{2}$ Pada penelitian kami, 3 subjek sembuh tanpa pengobatan dan 4 mendapatkan terapi simtomatis untuk gejala PHS yang timbul. Kontroversi pemberian terapi kortikosteroid terutama dikaitkan dengan waktu tepat pemberiannya. Saat ini, kortikosteroid telah banyak digunakan untuk mengobati PHS dengan manifestasi gastrointestinal dan ginjal. ${ }^{25}$ Pada penelitian kami, kortikosteroid merupakan terapi terbanyak yang digunakan yang terdiri atas metilprednisolon, triamsinolon, dan prednison. Weiss $\mathrm{dkk}^{8}$ juga mendapatkan kortikosteroid sebagai terapi terbanyak yang digunakan pada pasien rawat inap PHS, 
tetapi dengan persentase yang lebih kecil dibandingkan penelitian kami, yaitu 56\%. Perbedaan tersebut dapat disebabkan karena belum ada kesepakatan tentang kapan waktu tepat pemakaian kortikosteroid pada PHS sehingga keputusan penggunaannya akan dipengaruhi oleh penilaian klinis dan rekomendasi rumah sakit masing-masing.

Lima subjek dengan nefritis PHS berat mendapatkan terapi imunosupresif berupa siklofosfamid atau azathioprin yang dikombinasikan dengan kortikosteroid. Empat subjek dengan pemberian siklofosfamid pada akhir pemantauan memperlihatkan hasil urinalisis dan laju filtrasi glomerulus normal. Penelitian Tarsish $\mathrm{dkk}^{26}$ menunjukkan hasil pengobatan yang tidak bermakna antara kelompok yang diberi terapi kombinasi siklofosfamid dan steroid dengan kelompok tanpa terapi kombinasi.

Purpura palpabel nontrombositopenia dapat menetap sampai beberapa minggu. ${ }^{6} \mathrm{Kaku} \mathrm{dkk}^{27}$ mendapatkan purpura palpabel persisten lebih dari 1 bulan sebagai salah satu prediktor awal nefritis PHS. Pada penelitian kami, purpura menghilang dalam waktu 4 minggu pada semua subjek. Pada 1 subjek, penelitian gejala gastrointestinal dan artritis/ artralgia menetap lebih dari 4 minggu. Hematuria dan proteinuria kembali menjadi normal dalam jangka waktu 6 bulan secara berturut-turut pada 18/24 dan 13/17 subjek penelitian kami. Hasil tersebut sesuai dengan berbagai literatur yang menyatakan sebagian besar prognosis nefritis PHS pada anak adalah baik. ${ }^{6,22}$ Studi oleh Wakaki $\mathrm{dkk}^{28}$ menyatakan bahwa gambaran sindrom nefrotik saat permulaan sakit yang berlangsung selama 3 bulan merupakan prediktor buruk terjadinya gangguan fungsi ginjal permanen pada nefritis PHS anak. Pada 1 subjek penelitian kami yang mengalami penurunan fungsi ginjal dan gambaran sindrom nefrotik saat permulaan sakit, mengalami perbaikan fungsi ginjal setelah 20 bulan pemantauan. Tidak ada pasien yang mengalami gagal ginjal terminal pada penelitian kami.

Rekurensi dapat timbul pada sepertiga sampai setengah kasus dalam jangka waktu 6 minggu atau bertahun-tahun setelah gejala awal timbul. ${ }^{29}$ Trapani $\mathrm{dkk}^{22}$ menemukan episode rekurensi pada satu pertiga subjek penelitiannya dalam waktu satu tahun pertama sejak awitan sakit. Pada episode rekurensi, gejala yang timbul lebih ringan dengan jangka waktu lebih pendek tanpa disertai hematuria atau proteinuria. Pada penelitian kami, rekurensi dialami 5 subjek penelitian dalam jangka waktu 1-36 bulan pasca perbaikan gejala awal. Gejala yang timbul tidak lebih ringan dibandingkan saat awitan sakit, berupa purpura yang disertai dengan gangguan ginjal atau gastrointestinal. Jumlah subjek yang mengalami rekurensi lebih kecil dibandingkan studi Trapani. Hal tersebut dapat disebabkan waktu pemantauan yang sangat bervariasi pada data kami sehingga masih terdapat kemungkinan pada beberapa subjek timbulnya rekurensi tidak tercatat.

\section{Kesimpulan}

Manifestasi klinis tersering pada PHS adalah purpura palpabel, gangguan gastrointestinal, artritis atau artralgia, dan keterlibatan ginjal, sedangkan yang jarang adalah gangguan neurologis dan edema skrotum. Pemeriksaan darah perifer lengkap dan urinalisis sebaiknya dilakukan pada semua pasien PHS untuk mendukung diagnosis dan menilai keterlibatan ginjal. Pada semua pasien PHS, sebaiknya dilakukan pemantauan minimal selama 6 bulan untuk menilai keterlibatan ginjal yang mungkin timbul terlambat serta rekurensi.

\section{Daftar pustaka}

1. Tizard EJ. Henoch-Schönlein purpura. Arch Dis Child 1999;80:380-3.

2. Szer IS, Pierce H. Henoch-Schönlein purpura. Dalam: Horchberg MC, Silman AJ, Smolen JS, Weinblatt ME, Weisman $\mathrm{MH}$, penyunting. Rheumatology. Edisi ke-5. Philadelphia: Mosby Elsevier; 2011. h.1587-96.

3. Saulsburry FT. Epidemiology of Henoch-Schönlein purpura. Cleve Clin J Med 2002;69:SII 87-9.

4. Kumar L, Singh S, Goraya JS, Uppal B, Kakkar S, Walker R, dkk. Henoch-Schönlein purpura: the candigardh experience. Indian J Pediatr 1998;35:19-25.

5. Yang YH, Hung CF, Hsu CR, Wang LC, Chuang YH, Lin YT, dkk. A nationwide survey on epidemiological characteristics of childhood Henoch-Schönlein purpura in Taiwan. Rheumatology 2005;44:618-22.

6. Lanzkowsky L, Lanzkowsky S, Lanzkowsky P. HenochSchönlein purpura. Pediatr Rev 1992;13:130-7.

7. Scheinfeld NS, Jones EL. Henoch-Schönlein purpura. (Diakses pada tanggal 1 Maret 2009). Didapat dari: http:// emedicine.medscape.com/articlel. 
8. Weiss PF, Klink AJ, Hexem K, Burnham JM, Leonard $\mathrm{MB}$, Keren R, dkk. Variation in inpatient therapy and diagnostic evaluation of children with Henoch-Schönlein purpura. J Pediatr 2009;155:812-8.

9. Weiss PF, Klink AJ, Localio R, Hall M, Hexem K, Burnham JM, dkk. Corticosteroids may improve clinical outcomes during hospitalization for Henoch-Schönlein purpura. Pediatrics 2010;126:674-81.

10. Safri M, Kurniati N, Munasir Z. Pemberian steroid pada purpura Henoch-Schönlein serta pola perbaikan klinis di departemen ilmu kesehatan anak FKUI/RSCM jakarta. Sari Pediatri 2008;10:268-71.

11. Ozen S, Ruperto N, Dillon MJ, Bagga A, Barron K, Davin JC, dkk. EULAR/PReS endorsed consensus criterian for the classification of childhood vasculitides. Ann Rheum Dis 2006;65:936-41.

12. Gonzalez-Gay MA, Calviño MC, Vazquez-Lopez ME, Porrua CG, Iglesias JLF, Dierssen T, dkk. Implications of upper respiratory tract infections and drugs in the clinical spectrum of Henoch-Schönlein purpura in children. Clin Exp Rheumatol 2004;22:781-4.

13. Rai A, Nast C, Adler S. Henoch-Schönlein purpura nephritis. J Am Soc Nephrol 1999;10:2637-44.

14. Yang YH, Huang YH, Lin YL, Wang LC, Chuang YH, Yu $\mathrm{HH}$, dkk. Circulating IgA from acute stage of childhood Henoch-Schönlein purpura can enhance endothelial interleukin (IL)-8 production through MEK/ERK signaling pathway. Clin Exp Immunol 2006;144:24753.

15. Huber AH, King J, McLaine P, Klassen T, Pothos M. A randomized, placebo-controlled trial of prednisone in early Henoch-Schönlein purpura. BMC Med 2004;2:7.

16. Tohmaz MM, Saleh SI, Al-anezi F. Henoch-Schonlein purpura: presentation patterns in arab children in kuwait. Middle East J Fam Med 2008;6:issue 1.

17. Coppo R, Amore A, Gionoglio B. Clinical features of Henoch-Schönlein purpura. Ann Med Interne 1999;150:143-50.

18. Aalberse J, Dolman K, Ramnath G, Pereira RR,
Davin JC. Henoch-Schönlein purpura in children: an epidemiological study among Dutch paediatricians on incidence and diagnostic criteria. Ann Rheum Dis 2007;66:1648-50.

19. Kalman S, Ibrahim AH, Atay A. Henoch-Schönlein purpura in a child following varicella. J Trop Pediatr 2005;51:2401.

20. Widjajanti M. Manifestasi dan komplikasi gastrointestinal pada purpura Henoch Schonlein. Sari Pediatri 2012;13:334-9.

21. Aki K. Childhooh Henoch-Schönlein purpura in middle east country. Saudi J Kidney Dis Transplant 2007;18:151-8.

22. Trapani S, Micheli A, Grisolia F, Resti M, Chiappini E, Falcini F, De Martino M. Henoch Schönlein purpura in childhood: epidemiological and clinical analysis of 150 cases over a 5-year period and review of literature. Semin Arthritis Rheum 2005;35:143-53.

23. Kraft DM, Mckee D, Scott C. Henoch-Schönlein purpura: a review. Am Fam Physician 1998;58:411-2.

24. Narchi H. Risk of long term renal impairment and duration of follow up recommended for Henoch-Schönlein purpura with normal or minimal urinary findings: a systematic review. Arch Dis Child 2005;90:916-20.

25. McCarthy HJ, Tizard EJ. Clinical practice: diagnosis and management of Henoch-Schönlein purpura. Eur J Pediatr 2010:169;643-50.

26. Tarsish P, Bernstein J, Edelmann CM. HSP nephritis: course of disease and efficacy of cyclophosphamide. Pediatr Nephrol 2004;19:51-6.

27. Kaku Y, Nohara K, Honda S. Renal involvement in Henoch-Schönlein purpura: a multivariate analysis of prognostic factors. Kidney Int 1998;53:1755-9.

28. Wakaki H, Ishikura K, Hataya H, Hamasaki Y, Sakai T, Yata N, dkk. Henoch-Schönlein purpura nephritis with nephrotic state in children: predictors of poor outcomes. Pediatr Nephrol. 2011;26:921-5.

29. Ronkainen J, Nuutinen M, Koskimies O. The adult kidney 24 years after childhood Henoch-Schönlein purpura: a retrospective cohort study. Lancet 2002;360:666-70. 